\title{
Pathology of Promotion of the Juridical-Islamic Management and Presentation of the Needed Techniques
}

\author{
Taher Alimohammadi ${ }^{1}$, Seydeh Neda Jamshidi ${ }^{2, *}$ \\ ${ }^{1}$ University of Ilam, Iran \\ ${ }^{2}$ Jurisprudence and Principles of Islamic Law of Ilam University, Iran \\ *Corresponding Author: sadat.jamshidi@yahoo.com
}

Copyright $@ 2014$ Horizon Research Publishing All rights reserved.

\begin{abstract}
Islam encompasses all of the plans of the human life in all of the periods and places. This religion guides the humans with the explanation of the beliefs in the thought terms, with the fulfillment of the moral values in the carnal terms, and with the encouragement and suggestion to act the religious rules in the behavior terms. So, the role of the Islamic and juridical management in the explanation and Institutionalize of these cultures especially in the field of the religious rules and controlling of them is undeniable and is regarded by the sacred legislator. But, the very management can encounter with the harms, obstacles and problems and loses its function. The present research that has been conducted by the descriptive method has investigated the harms and obstacles of the juridical management with the explanation of its unique place and privileges and has suggested some ways for the solution of the existent problems.
\end{abstract}

Keywords Islamic Management, Juridical Management Obstacles, Harms

\section{Introduction and Definitions}

Management meaning: "manager" word means a person who manages, subject noun, Tri more from the infinitive of (edareh), babe Ef'al and "management" is its gerund. (Sher tooni, 242:14.3).

Moreover, the words of manager and management have primarily taken from the root of (Davar) that its infinitive is Davaran that means « gardidan», then, manager means "gardanandeh". So, the management includes every kind of directorship in every level and the order concepts such as the leadership, guidance and etc, can be considered as its inclusion cases in a higher level. Various idiomatic definitions have been submitted for the management meaning that are as the following:

1. Management means acceptance of the responsibility for the guidance and controlling of the organization for achieving the desired purpose and fulfillment of the intentions (Taghavi, 20:1989).

2. Management is a process by which the individual and group endeavours are harmonized with each other in order to reach the common or shared purpose.

3. Shahid (Martyr) Motahari definition of the management is that: the human management and their leadership mean the technique of better mobilization, better regulation and better controlling of the human forces and their application. (Motahari, 235,2008).

\section{Islamic Management Concept}

Islamic management is a management that provides the background of the human growth towards God. And acts according to the book, traditional and the method of prophet and innocent Imams (pace be upon them) and the sciences, techniques and the experiences of the human as an axis, an orbit and a polar in order to reach the purposes of a system in the different dimensions. (Javadi- Amoli,4:1398). Of course, we means by the Islamic management, a Juridical management; namely, a management that a learned and fair Jurisprudent is in its top. According to this definition, the Juridical-Islamic management guides the society based on the faith in God and the recognition of God book and the tradition of the Innocents (Masoomin) and acts and controls under the limits of the religion and the Islamic religious rules (Emamieh) and regulates the ideal Islamic society by the enforcement of its principals.

\section{Management significance}

Given the complexity and sensitivity of the control of the human affairs, the management knowledge and technique is very important. The management is one of the elements of the social life, because in the society, the interests, intentions and destiny of the people are related each other. The management is very important in the life so that all of the creatures that live socially, choose a manager Based on Instinct and the humans need organization, planning and a system that guide them towards their purposes. In a hadith of 
Imam Ali(pace be upon him), it is stated that: " in the customs and the way of the life, people are more similar to the managers rather than their parent." (Ibne Shobeh harani, 208,2003). The management and its techniques and education of competent managers are the most important religious and conceptual principals. Human can't live in a disharmonious way and as a jar in the world. When he distances from the system, organizations and the management, he will encounter with the failure and is condemned to the doom. (Makareme shirazi,22-21:1993).

Management in all of the levels is a kind of the guidance and leadership of a group of the humans and is very important. Management is the pillar of the tent of the organization and the consolidation of every organization depends on the ability, fidelity, tact and the strength of the management, and as Imam Ali comments: the leader place is as a firm string that unifies the heads and linked them to each other; if this string is torn, the heads will be scattered and each of them goes to a direction and aren't collected at all. Shahid Motahari named three main principles in relation to the significance of the management and leadership place: the first principle is related to the significance of the human and the forces that are hidden in him and usually he ignored them. In Islam, the matters of alert the human to himself, to his greatness, honor and the great forces in him have been considered. (Motahari,30:2006). So, what exists on the earth has been created for the human and taken by his forces. «it is he who created for you all that is in the earth» (Cow,26). (and he has subjected to you what is in the heavens and what is in the earth).(13-Hobbiling)

The second principle is related to the difference between the human and animal. The animals are equipped with a series of the instincts and don't need the external leadership and management, because the instinct guides automatically. But the human is the poorest and the weakest creature in terms of the instincts that guide him internally. Then, he needs the external leadership and guidance. This is the very principle that is the basis and the philosophy of the prophets be'sat ; the human is a creature equipped with the

Infinite power resources and reservoirs, but he is very ignorant and wanderer and he is unaware of its self-existence, he doesn't know what he has and doesn't know how guides and exploits of it; so, it should be guided, the way is shown to him and his forces are organized, he should be freed and moved. The third principle is related to the especial rules of the human life. A series of the principles rule on the human behavior that if a person wants to manage the human and guides him, this is not possible but through the recognition of the rules that dominate on the life and the routine life of the human. So, the human is a creature that his leadership and moving and exploitation of his forces depend on a series of the very exact rules that their recognition is the key of the way of penetration in the hearts and dominate on the humans. (very.32). in this between, the Juridical management becomes more important; because in the Islamic system

\footnotetext{
${ }^{1}$ Being chosen as God's messenger.
}

(Valie Faghih). The top, manager in addition to the management principle and his proper enforcement, should control the society only in the limits of the religion and the juridical rules and takes care of the religion, its rules and the proper enforcement of the religious regulations in addition to the order regulations of the society as an alert and sharpsighted guard, and it is obvious that the leadership of the humans and mobilization of their big hidden forces towards perfection is the best and the most difficult human rank in terms of the social aspect and this world life and in terms of the spiritual aspect and the ways towards God. (Motahari,35,2008).

\section{Management place}

Every society although small one such as the population of a family, if it wants to be organized, it should have a chief or a head otherwise, disorder and chaos will be dominated on that society. ( Mazaheri,51:2006). Koran has stated this topic but it has used the word of Ghavam (firmness) for the presidency and management $\ll$ men are the managers of (women,340) the affairs of women» .

«the prophet is nearer to the believes than their selves». (6. Confederates). Sheikh Toosi has interpreted « nearer to the believers» as «more competent in their prudence», it means that the prophets are more competent than the others for the prudence and controlling of the people. (Sheikh Toosi, bi-ta:8/317).

Abolfotouh Razi quotes from some of the commentators that it means that God's prophet is more competent than the nation in the signature of the rules and establishment of the limits and commanding on them. (Abolfotouh Razi,336/15:1408). This priority isn't allocated to the religious issues and encompasses all of the world and religion affairs of them. So, people should follow the orders of God prophet and avoid what he prevent and prefer his wills to their desires and recognition. (Zomokhshery, 523/3:1407 and Alameh Tabatabai, 276/16:1417). There are some anecdotes in the confirmation of this interpretation that say that we mean by the priority, the commanding rank, recruitment and زعامت and this verse has been sent for the leadership and commander ship. (Kelini, 834/2:1996).

Emam Khomeini states that: " no one but God has the right of legislating, and God- as the wisdom commands-should establish a government for the people and legislates. But, law is one that Islam has legislated it and afterwards we confirm that this law is for every one and for ever». (Emam Khomeini, bi-ta:184).

Presidency and supervision is a rational matter and has been emphasized by Islam. So, the management is very important in every office and organization whether it is ungodly or divine one. Imam Ali says that:«the existence of a ruler is very important for the people whether they are benefactor or evildoer». Islam believes that managing of the people is one of the divine tests because the persons who are in this position are tested with the responsibility.

Imam Ali (peace be upon him) says: the presidency and governing are the fields for testing of the men. 
(Nahjolbalagheh,89:1414). So, the Islamic (Juridical) management is different with the other managements in terms of the nature, purpose, intention, value and tool. The Islamic management is a responsibility and a duty, for approaching God. The Islamic management is Vajebe Kafai and isn't material and it is natural that we can't pollute by another sin in the way of doing of a necessary affair. Purity, belief and avoidance of violation and sin should be existed throughout the way, a way that leads to the divine domain and the religious values, and should reach an Islamic purpose in which the humans growth namely their intellectual and material growth is posed in the framework of a complex that an Islamic manager has taken its responsibility. Undoubtedly, in the course of enforcement of this management, the manager isn't authorized to resort to any approach. He can use only the methods that are allowed in Islam and human terms. He can't exert his management by force, subornation and deception. And provides the conditions of its management continuation through the ways contrary to Islam that is in its tern in the principle contrast with the nature of the Islamic management. (Kharazi, 26:1999).

\section{Issue Expression}

The government controlling needs the «scientific management».

Whether the juridical management that is based on the jurisprudence can control the country?

Answer: some have said that there is not any word of the development and leadership in the religion and these affairs are in the control of the science and wisdom. They are mistaken and have found the source of the religion in the narrative reason (Koran and narratives), and so have thought that the religion is in sufficient and inaudible, and then have considered the scientific management against the juridical management. But, the religion source encompasses the narrative and the wisdom reason;

Namely, what the wisdom considers as logic, it is the religion fatwa, in all of the principles books, the rich resources of the jurisprudence are Koran, tradition, wisdom and consensus and although the consensus refers to the tradition, but the wisdom resource is an independent source and if the planning of the development of the country and regulation of the internal and external policies are based on the common sense and far from the carnal desires, they are related to the religion. The wisdom and narration are two eyes of the religion rules, that the wisdom expresses the religion idea about the materials that aren't observe in the narration namely the book (Koran) and tradition. The problem is that some have separated the wisdom from the religion and in opposition of it. While, the wisdom isn't against the religion at all; the wisdom is against the narration and both of them are the subsets of the religion. (Javadi, Amoli,2013).

The research method: this research has been conducted by the analytic- descriptive method and by the library studies and searching in Koran text and the related interpretations and the analysis of the juridical matters.

Theoretical principles: Islamic management characteristics: some of the Islamic management characteristics are as the following:

1. Monotheism centrality and divine should and shouldn't

2. Leader jurisprudence.

3. being exploratory.

4. Greatness and valuation

5. Globalization

6. Harmony with the human nature.

7. Public responsibility and supervision. The harms that the juridical- Islamic management are encountered with (them):

1. Innovation: whatever is occurred after the prophet and when the religion was completed, is innovation. (Farahidi,55/2"1410, Johari, 1184/3:1410).

Innovation means somebody enters something in the God religion that is not from the religion and forges and devises a thing that is not related to the religion. (Motahari, 42/5:1996).

Prophet comments a sermon that: the best Hadith and word is the God book and the best guidance and way is the guidance of Mohammad, and the worst affairs are what mostly created, and what is created is innovation, and what is innovated is deviation. Imam Ali states in the 53 letter of Nahjolbalaghe that: don't disrupt, the acceptable customs that the leaders of this nation acted them and Islam nation are linked with them and peasant improved by them, and don't create the customs that damage the last good traditions. The religious society is a society that values the essence of the religion enforcement. Now if the innovation takes the place of the religion, in fact, the religious order of the society has been disrupted. The first purpose was that Islam has had a kind of dominance and the religion is revived, as it has been stated that: Imam Wants to reform the territories establishes the justice, but when the innovation is dominated instead of the religious rules, it is the first disorder that is created in the society. Before the tenure of Imam Ali, the behaviors were based on the non- nabavi tradition and this issue was posed as a value so that Osman in Mena perform 4 rak'ats namaz completely while he should perform it in short, and also was proud of this, and when the Muslims opposed with him, he said in any way I had this right to express some of the rules in other forms (klini,149/4:1996). It has been stated in the narratives that: if somebody meets a man of innovation, he has disrupted the religion. Namely, if somebody creates an innovation in the religion, the others are forbidden to meet him. The innovation word is a key connect in the politicalreligious thought of Imam Ali. When the innovation is occurred, the Islamic society is exposed to all of the difficulties, and it is in this course that sedition is created. (Nahjolbalagheh.234:1414).

2. Sedition: innovation is followed by sedition. Sedition means whatever by which the population are tested, and inevitably it should be something that the population tolerate 
it with difficulty. (Tabatabai,75/9:1477). Alameh Tabatabai has stated in the (Tafsir-Al-Mizan) that: "ssome orders have been given in Koran for the preservation of the basis of the religious mass life and creation of the Islamic order that if they don't observe the sedition will be created (very, 259/9). It has been stated in Koran that: unless you do this, there will be persecution in the land and great corruption (the spoils/73). And «seeking to stir up sedition between you». (Repentance/47) it seems that sedition is a kind of riot and a kind of deep disagreement and is a general disorder in the society. Syoti has stated a narrative in "Almansoor» that Osman wanted to delete $\langle\mathrm{VaV}\rangle$ from repentance Surah, because when (vav) was removed, Those who is related to the previous expression, it means that if unbelievers and the man of book collect the property, they go to the hell, but if (vav) remain, it also includes the Muslims, namely the Muslims that collect the property. Abi ebne Kaab came and said: if (vav) is removed, I will fire myself. (Syooti,2321,3:1404), it means that sometimes removing or remaining of (vav) can create two kinds of Islam; one is the real Islam and the other is the wrong Islam. In fact, sedition is occurred when the wrong group can't resist against the right group, then they begin to cause sedition that is originated from the innovation, and in this case one group supports the right and the other group defends the wrong, and this leads to the rift that is the most dangerous difficulty for the Islamic society.

3. Doubt: as we mentioned, innovation was originated from the sedition. Now, we should know that the seditions lead to the doubts; because, the public can't distinguish the right from the wrong. So, sedition and doubt are a triangle that create and complete each other. In a letter, Imam Ali addressed Maleke Ashtar sharply: «this religion was involved in the hands of the wrong doers in which they acted capriciously and was claimed with the name of the religion . »(Nahjolbalagheh,435:1414).

So, determination of the right from the wrong was difficult. «No innovation was created but that by which they left a tradition; then, separate yourselves from the innovation and move towards the straight path. The best of the affairs is a tradition that is an ancient one and it backed to many years, and the worst of them is what has occurred recently and hasn't had a background».(very, 202).

Innovation is a creator of the sedition and sedition is resulted in the doubt, riot and conflict and then leads to the fading of the government. Imam Ali analysis is that in these conditions, the right and wrong are mixed and it this situations whatever you speak of the right, no one can distinguish in from the wrong words, and then, the decision-making is difficult and even the devout persons and those who pretend they are loyalty to the religion aren't ready to approach this government and become isolated and evade from involving in the endeavors that are in the benefit of the government. It is difficult to release from the situation in which, sedition and innovation are cooperated each other. So, Imam Ali explains the conditions in this manner that: but, today we fight against the Muslim brothers that ambivalence and trick have entered their Islam, and the doubt and commentary have penetrated in the belief and certainly. We means that we don't have a unified interpretation and we have own interpretation of it, so that it has been common among the people that there are two or three kinds of Islam and it is one of the most deadly things for the Islamic society. The society that has been affected by the doubt and sedition, will certainly suffered from the conflict and dispersion especially if the disagreement is followed by the carnal desire and also if the faction and tribal conflict is added to this event, in these conditions, the society is affected by a fission that no longer one can organizes it and even Imam Ali can't reorganize this society, and so he resents from the people and recommend them that: indeed, what that hadn't existed previously in the religion and has been created recently, and what that isn't a tradition and is as the tradition head to the destruction of the nation, unless God shows mercy and protect the creature from it. (very,243). Indeed, the government that is established by God, is the guard of your affairs, then observe its command but not because of the tedium or because of reluctance to it(very,243). Therefore, the existence of these three concepts (innovation, sedition and doubt) naturally eliminates the cohesion of the society and creates the tribal society and leads to the dominance of the kinds of the deviations on the society.

4. Right rejection (denial):People in every society should observe the conditions dominated on that society. No, if the society don't follow the orders of the its leader and manager and tries to evade from the justice of the Islamic government, there is no conclusion but the existence of the disruption of the situation and discord, and it is in turn the biggest obstacle in the exertion of the Islamic government and its development. For the Muslims, the right and justice mean the fulfillment of the commands of God that have been shown the Muslims by prophet and A'emme Ma'soomin (innocents Imams). Hazrate Zahra (peace be upon her) stated that 2 : God has shown the obedience from we, Ahle beit $^{2}\left((1)^{*}\right)$ as the factor of the establishment of the social order in the Islamic nation and Imamate and the leadership as the factors of the unity and surviving from the discords». (Tabarsi,99/1:1403, and Majlesi,158/43:1403). So, the realization of a prosperous society needs the fulfillment of God and Imams.

Imam Ali states that : O', different ( diversity ) population and dispersed hearts, $\mathrm{O}^{\prime}$, you that your bodies are existent and your wisdoms are hidden from you, I draw you towards the right and when I want to exert the justice, you run wild as the running wild of a Capricorn from the roar of a lion! It is impossible that I remove the darkness from the justice face or straighten the bent that has approached the right.

5. Presidency claiming: Presidency claiming is among the scourges of the Islamic management that leads to the declining of a government. Imam Reza(peace be upon him) states that: «the damage of two hungry wolves to a sheep flock without shepherd is not more than damage of the presidency claiming to the Muslims

\footnotetext{
${ }^{2}$. The household of the prophet of Islam
} 
religion»(Kafi,297/2:1407).

Imam Sadegh (peace be upon him) states that: «avoid from the presidency claiming that no one claims it unless he is wiped out».(Sedoogh,180:1403). The obstacles that the juridical-Islamic management is encountered with (them) in the society:

1. Penetration of the western management;

2. The lack of familiarity with the juridical management;

3. The lack of strategic glance to the Islamic management topic;

4. Inattention toward the conduction of the different researches about the Islamic management.

The ways for evading from the obstacles and the difficulties that the Islamic management is encountered with them:

After the mention of the damages and obstacles in the course of the realization of the Islamic management, now it is the time for the mention of some important issues and the key points that can lead to our evading from these problems, some of these cases are as the following:

\section{Reliance on the Faith Force}

Faith in God and the from belief in god orders lead to the reinforcement of the morale and increasing of the ability of confrontation with the problems and intrigues. In this case, the managers should increase the capacities that God has deposited in their existence and regard more to their self -recognition, self- education and proliferation of the high characteristics and then correct and improve their relation with God and then provides the possibility of creation of more appropriate environments for their co-workers by application of the management techniques fitted with the situation and conditions. Koran considers the faith as grace and blessing of God. «but, God has endeared to you belief, decking it fair in your hearts, and he has made detestable to you unbelief and ungodliness and disobedience. Those- they are the right minded, by God's favor and blessing; God is All-knowing, All-wise. (Apartments/ 7 and 8), and addresses those who become a Moslem that: God confers a favor upon you, in that he has guided you to belief, if it be that you are truthful. And finally states that: "surely, those who believe, and do needs of righteousness- surely we leave not to waste the wage of him who does good works»). (Cave,30). Undoubtedly, the effect of this kind of view leads to the appearance of the especial characteristics in the humans that also the others are affected by it. This issue make the role of the managers as a guidance and pattern more prominent in one hand and in other hand, it exposes more real symbol of the Islamic management at the vision, judgment and adaptation.

\section{Preservation of the Unity and Avoidance from Scattering (Divergence)}

Preservation of the unity in words is among the basic principles for the Islamic society. Unity is against the duality and fission. The health society is a society that is far from the divergence and pluralism. Such society can traverse the welfare way. God states that: «be not as those who scattered and fell into variance after the clear signs came to them; those there awaits a mighty chastisement».(house of Imran103), and addresses prophet to say the people that: $\mathrm{O}$, people! In need, god has sent me for all of you. (Battlements/158). What is this very emphasis for? Prophet states that « God is kind to the people. (Mofid,237:1413 and Motaghi Hendi.206/1:1397). So, everyone who opposes the people, he will be astray every moment», because «the power altogether belongs to God». (cow,165). But glory altogether belongs to God. (women, 139). "God's is the devising altogether. (Thunder,42). « to God belongs intercession altogether».(companies/44). «but God's is the affair altogether» .(Thunder,31). Imam Ali says: the best of the people are the moderate group, don't separate from them. Always stay with the biggest populations that God is kind to the crowed. Avoid from the dispersion. Be aware that everyone who invites the people to this slogan (discord and separation), kill him although he is under my turban and the only reason that those two persons (Aboomousa and Amroas) were polled to judge was that they live what Koran lived and kill what Koran named dead, in this case, to bring to life means being unity with each other and killing means elimination of the dispersion and separation.

\section{Self- belief}

It seems that our society as most of the developing societies needs self- belief and self-reliance in many fields evading from the debility belief and achieving the self- belief in any field need the brave and indefatigable pioneers who are familiar with that issue. It is true in the field of the management and this purpose is to achieved due to the endeavors of the scholars and experts and those who are familiar with the Islamic sciences. In Koran, God encourage the believers to Jehad, self- belief and faith in right and says: $\mathrm{O}$, prophet, urge on the believers to fight. If there be twenty of you, patient men, they will overcome two hundred; if there be twenty of you, patient men, they will overcome a thousand unbelievers, for they are a people who understand not». (Spolis/G5).

So, self- belief is among the affairs that the lack of it , weaken the foundations of the faith and postpones Jehad in the way of God and reaching the desired society. God after the expression of this blessings to the human mention that the human is respectful and it is the biggest confidence for the believers that believe their abilities and talents.(wow we have sent down to you a Book where in is your remembrance; will you not understand?» (the prophets/10).

\section{Clarification of the Limit and Boundaries of the Islamic Management}


In any society, the managers such as Islamic society need the planning, organization and application of the traditional techniques and methods and in this direction these methods mostly are similar with each other. But the Islamic management has priority over the western management due to the attention to the other fields that so far has considered less by the western management. Also, the scholars authorize significant theoretical principles in this field that by which we can apply these theories in the organizational level. In fact, we can use its tools, methods and the techniques for the realization of the Islamic management and exploit from the other characteristics of the Islamic management that lead to the priority of this approach over the other management approaches. For the creation of the Islamic organization, we can say that Islam doesn't offer the scientific rules of the management rather it gives us the management rules and principles that whereby we use mostly the tools of the scientific management and cause the science to be at the service of the system of the Islamic management. In fact, Islam has determined the limits (frameworks) - and leaves the human to enjoy the scientific findings under this framework, not manages based on his knowledge. In other words, science is the human finding and changeable that makes the management rules and methods, while the religion is the divine Vahy (divine message) and unchangeable and clarifies the management principles. What is important, is that all of the managers and planners in the various arenaswhile using of the best and the most efficient scientific methods should always observe the religion values and use the religion norms accompanied with the scientific innovations, because the science by itself doesn't follow a certain purpose in the management system and the net(pure) scientific management doesn't exist in reality. In any way, when the characteristics of the management in the societies are fitted with the given value and cultural structure of the society, they can lead to the efficiency of the management and increase of the exploitation and efficacy in the organizations, as the blindly and without norm using of the ready orders and volumes of the west management can disrupt the coherence and order of the societies and leads to the crisis and the different social and economic problems in the societies.

\section{Fulfillment and Submission of More Researches about the Islamic Management}

Given the important and determinant role of the research in all of the scientific fields, also the Islamic management needs the presence and diligence of the researchers and experts. These researches should be conducted in the organizations levels and then be tested end experienced. Publication of the conducted researches and their results can lead to the familiarity of most of the public and also the students, researchers and experts of the management with the capabilities of the Islamic management in the increase of the exploitation, efficacy and job satisfaction and etc., and even the criticism from the published views and endeavor for the improvement of their weak points can lead to the exaltation of these theories.

\section{Conceptual Model}

This model has been designed by the writers.

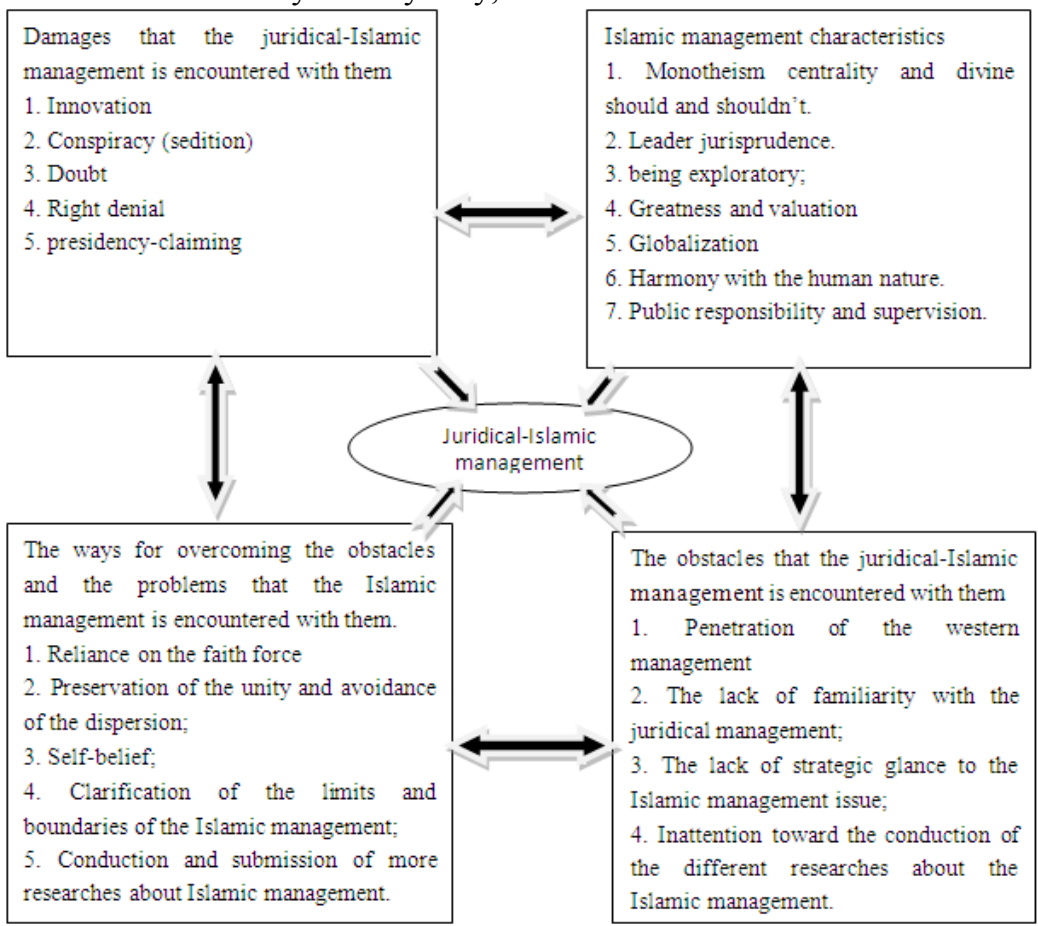




\section{Conclusions and Suggestions}

The results of the previous discussions are as the following:

1. The human needs the outside leadership, management and guidance because in one hand, the interests, intentions and destiny of the society people are related with each other and in other hand, unlike the big forces and resources that exist in the human, he is the poorest and the weakest creature in terms of the instincts that guide him internally. Moreover, if somebody wants to manage the human and guides him, it is not possible but through the recognition of the rules that dominate on the life and the human life style; here, the necessity of the juridical-Islamic management in the Islamic society is appeared, because the juridical manager is the very person who knows the ruled dominated on the human life by using of the valid religious resources.

2. The juridical-Islamic management is different with the other managements in terms of the nature, purpose, intention, value and tool. The Islamic management is Vajebe Kafai and it is considered as a responsibility and duty and in the course of exertion of this management, the manager isn't authorized to resort to any tools that are authorized in the human and Islamic view.

3. Some of the advantages of advantages of the Islamic management to the other managements are: Monotheism centrality and divine should and shouldn't jurisprudence and the justice of its leadership, being exploratory, being responsible, Greatness, Value orientation and its humanism, being global(universal), harmony with the human nature and the public responsibility and supervision. The juridical management is based on the high principle of the human and the goods production and the development in the industry and technology are valuable when they are at the service of the growth and promotion.

4. The damages that the juridical- Islamic management is encountered with them, are: innovation in the religious affairs, creation of the sedition in the Islamic society, creation of the doubt in part of the demagogues, denial of the right and presidency-claiming. But, the obstacles that the juridical- Islamic management is encountered with them are varied; some of them are: penetration of the western management in the society, the lack of familiarity of the low-level managers and the public with the juridical-Islamic management, the lack of strategic glance to the Islamic management in the organizational levels and inattention toward the conduction of the different researches about the Islamic management in the organizational levels.

5. The way for overcoming the obstacles and the problems that the Islamic management are encountered with them, are: reliance on the force of the faith in God and the firm belief to (in) God orders, preservation of the unity of words a avoidance of the dualism and fission of the Islamic society, self- belief and self-reliance-clarification of the limits and boundaries of the Islamic management and the conduction and submission of more researches about the Islamic management.
6. Islam doesn't submit the scientific rules of the management but it introduces the rules and the principles of the management and whereby the tools of the scientific management have the maximum use at the service of the system of the Islamic management. In fact, Islam has determined the frameworks and allows the people to enjoy the scientific findings in the limits of this framework not exert the management based on their knowledge. In other words, the science is the human finding and is changeable and develops the rules and the methods of the management; while, the religion is the divine Vahy and unchangeable and clarifies the management principles.

\section{REFERENCES}

\section{[1] Koran (Quran )}

[2] Nahjolbalagheh (sobhi Saleh), Sharif razi- Mohammad Ebne Hossein, Hejrat,1 volume, first edition. Khom-1414-

[3] Ayati, Hamid; the constitution of Iran Islamic republic, Danesh Negar, Tehran,1379;

[4] Ebne Abi Jomhour, Mohammad Ebne Zein Aldin; Avaly-Allaly Al-Azizieh Fel Ahadis ol dinieh, 4volues, Daro-Seyed Al Shohada Alnashr, first Edition, Khom,1405.

[5] Ebne Asir Jazri, Mobarak Ebne Mohammad; Alnahayat fi Gharib Al Hadis Val Asar, 5 nolumes, Esmailian press institute. Forth edition, Khom,1367.

[6] Ebne Harani, Hassan Ebne Ali; Tohef ok Oghoul/ Janati translation, 1 volume, Amir Kabir institute, first Edition, Tehran, 1382-

[7] AbolFotouh Razi, Hossein Ebne Ali, Roz Al Janan va Rouh-Al-Janan Fi Tafsir Al-Koran-, Research; Yahaghi, Mohammad Jafar; advisor, Mohammad Mehdi, Islamic Researches institute of Astane Ghodse Razavi, Mashhad, 1408.

[8] Afjeh, Seyed Ali Akbar, Islamic management, Sajeh publication, fourth edition, Tehran, 1377.

[9] Taghavi, Seyed Reza, attitude over the Islamic management, Islamic propaganda organization, Tehran, 1368.

[10] Javadi Amoli, Abdollh, religion and the efficient management, Islam Pasdar magazine, No.269, ordibehesht, 1389.

[11] Johari, Esmail Ebne Hamad; Alsahah-Jaj-ol-Loghah va Sahah- ol- Arabieh, 6 volumes, Dar-ol-Elmol Malain, first Edition, Beirout, Lebenon, 1410.

[12] Hor Amoli, Sheikh mohammad Ebne Hassan, Tafzile Vasayel-Al- Shieh-Ela Tahsile Masael-Al-Sharieh, Ale beit institute, 30 volumes, first Edition, Khom, 1409.

[13] Khamenei Seyed Ali, resalehe Ojoubat-Ol-Esteftaat, Bein_Al Mallal publication corporation, Tehran, 1390.

[14] Kharazi, Kamal, introduction on the principles of the Islamic management, Oloum Tarbiati (educational science) publication, No.13, p-29-16, 1378.

[15] Zomokhsheri, Abolghasem, Mahmoud Ebne Omar; Alkeshaf An Haghaegh Ghavamez- Ol-Tanzil, Dar-Ol Ketab-Ol-Arabi, 
third Edition, Beirout, 1407.

[16] siouti, Jalal-ol-din; Al dar-ol-Mansour fi Tafsir-ol-Maasour; libarary of Ayat-ol-llah Marashi Najafi, Khom, 1404.

[17] Shertouni, Saiid-Al-Khouri; Aghrab-Al-Mavared fi Nesh-ol-Arabieh, school of Ayat-ol ozma Marashi, Khom, 1403.

[18] Shahid Sani, Amoli, Zein-ol-Dine Ebne Ali; AlRozat-ol-Bahieh fi Sharh-el-Maahol Dameshghieh(Al Mahashi- Kalantar), 10 volumes, Davari book shop, first Edition, Khom, 1410

[19] Sedough- Ebne babouyeh, Mohammad Ebne Ali, maANI-Al-Akhbar, 1 volume, Islamic publication office dependent on the teachers society of Ghom seminary, Ghom, first Edition, 1403.

[20] Tabatabai, Seyed Mohammad Hossein; Almizan fi Tafsitr-Al-Koran, Islamic publications society of ghom teachers society, fifth Edition, Ghom, 1417.

[21] Tabarsi, Ahmad Ebne Ali, Alehtejaj Ala Ahlel Jaj, 2 volumes, Morteza publication, Mashhad, first Edition,

[22] Tousi, Abou Jafar, Mohamad Ebne Hassan; Alameh, Dar-Al-saghafeh, 1 volume, first edition, Ghom, 1414.

[23] Al Tabyan fi Tafsir-Al-Ghoran, Dar Ehya-AlTeras-Al-Arabi-Beirout, Bita.

[24] Farahidi, Khalil Ebne Ahmad; ketab-Al-Ein, Hejrat publication, 8 volumes, second publication, Ghom, 1410.

[25] Kelini, Abou Jafar, Mohammad Ebne Yaghoub; Osoul-ol-kafi/ Kamarey translation, 6 volumes, Osveh, third Edition, Tehran, 1375.
[26] Motaghi Hendi, Ala-ol-din Ali Ebne Hessam, Kenz-ol-Emal fi sonan-ol-Aghval fi-Al-Afal, correction: Safvat-ol-Sagha, Maktabat-ol-teras-Al-Eslami-firsty Edition, Beirout, 1397.

[27] Majlesi, Mohammad Bagher Ebne Mohammad Taghi; Behar-Al-Anvar-Al-Jamee Ledrar Akhbar- Al-Aeme-Al Athar (T. Beirout),11 volumes, Dar Ehya -Al-TerasAl-Arabi- second Edition, Beirout, 1403.

[28] Motahari, Morteza; Imamat and leadership, Sadra publications, Tehran, 1387.

[29] Secret assistance in the human life (management and leadership in Islam). Sadra publications, Tehran, 1385.

[30] Familiarity with Koran, sadra publications, 8 volumes, Tehran-1385.

[31] Mazaheri, Hossein; Ethics in office; compilation: Khaleghi, Mohammad Javad, Islamic propaganda printing office, Boustan publication, fifth Edition, Ghom, 1385.

[32] Mofid, Mohammad Ebne Mohammad, Alfesoul-Al-Mokhtare- 1 volume, Sheikh Mofid, congress hom, first Edition, 1413.

[33] Al-Amali, 1 volume- Sheikh Mofid congress, Ghom- first Edition, 1413.

[34] Mousavi Khomeini, Seyed Rouh-Al-ah; Kashf-ol-AsrarAzadi publications, Ghom- Bita.

[35] Sahifeyeb Imam, publication and regulation institute of Imam Khomeini works; first edition, 1378.

[36] Nouri-Hossein Ebne Mohammad Taghi; Mostadrek-Al-vasael va mostanbed- ol-masael, 28 volumes, Ale Beit(peace be upon them) institute- first EditionGhom-1408. 